ISSN 1678-3921

Journal homepage: www.embrapa.br/pab

For manuscript submission and journal contents, access: www.scielo.br/pab

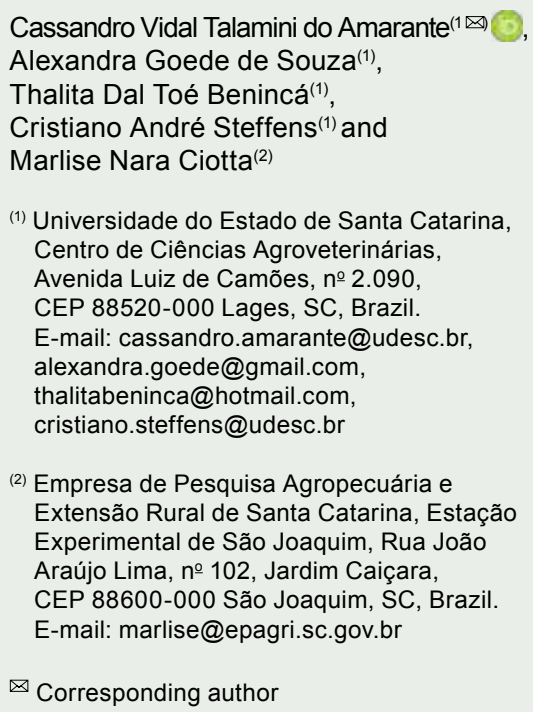

\section{Physicochemical attributes and functional properties of flowers of Brazilian feijoa genotypes}

\begin{abstract}
The objective of this work was to characterize entire flowers of the feijoa (Acca sellowiana) genotypes 'Alcântara', 'Helena', 'Mattos', 'Nonante', and the accession 2316 for dry matter, total antioxidant activity (TAA), and the contents of soluble solids, ascorbic acid, total anthocyanins, total flavonoids, and total phenolic compounds (TPC), as well as for the petal surface areas and colors. The TAA was quantified by the ABTS and DPPH methods. Flowers of the accession 2316 and of the cultivars Alcântara and Helena showed the highest contents of anthocyanins and flavonoids, as well as the highest values of TPC and TAA. The feijoa genotypes cultivated in Southern Brazil show high contents of soluble solids and represent a natural source of antioxidants.
\end{abstract}

Index terms: Acca sellowiana, anthocyanins, ascorbic acid, flavonoids, soluble solids, total antioxidant activity, total phenolic compounds.

\section{Atributos físico-químicos e propriedades funcionais de flores de genótipos brasileiros de goiabeira-serrana}

Resumo - O objetivo deste trabalho foi caracterizar flores inteiras dos genótipos de goiabeira-serrana (Acca sellowiana) 'Alcântara', 'Helena', 'Mattos', 'Nonante' e o acesso 2316 quanto à matéria seca, à atividade antioxidante total (AAT), e aos teores de sólidos solúveis, ácido ascórbico, antocianinas totais, flavonoides totais e compostos fenólicos totais (CFT), assim como as áreas e as cores das pétalas. A AAT foi quantificada por meio dos métodos ABTS e DPPH. As flores do acesso 2316 e das cultivares Alcântara e Helena apresentaram os maiores teores de antocianinas e flavonoides, bem como os maiores valores de CFT e AAT. Os genótipos de goiabeira-serrana cultivados no Sul do Brasil apresentam alto teor de sólidos solúveis e representam uma fonte natural de antioxidantes.

Termos para indexação: Acca sellowiana, antocianinas, ácido ascórbico, flavonoides, sólidos solúveis, atividade antioxidante total, compostos fenólicos totais.

Feijoa [Acca sellowiana (O. Berg.) Burret, Myrtaceae] is native to Southern Brazil and to the Northeastern of Uruguay (Ducroquet \& Hickel, 1991). The fruit has a singular sweet and sour taste and a very aromatic flavor (Amarante et al., 2017a), and its flowers are edible (Souza et al., 2016). Edible flowers, besides enhancing the appearance of prepared foods, are also an important source of bioactive compounds that help maintain and improve human health (Bazylko et al., 2014). These include phenols that have been attracting particular attention 
for their antioxidant activity and ability to scavenge different free radicals, leading to the protection of biological molecules against oxidation (Li et al., 2014). However, as far as we know, there are no reports concerning the characterization of phytochemical composition of feijoa flowers and the beneficial effects of its consumption.

The objective of this work was to characterize entire flowers of the feijoa genotypes 'Alcântara', 'Helena', 'Mattos', 'Nonante', and the accession 2316 for dry matter, total antioxidant activity, and the contents of soluble solids, ascorbic acid, total anthocyanins, total flavonoids, and total phenolic compounds, as well as for the petal surface areas and colors.

Feijoa flowers were harvested early in the morning (between 8:00 and 10:00 h) from the orchard of Empresa de Pesquisa Agropecuária e Extensão Rural de Santa Catarina (Epagri), in the municipality of São Joaquim, in the state of Santa Catarina, Brazil (28 $16^{\prime} 40^{\prime \prime} \mathrm{S}, 49^{\circ} 56^{\prime} 09^{\prime \prime} \mathrm{W}$, at $1,400 \mathrm{~m}$ altitude), in 2012, 2013, and 2014. Newly opened flowers (at the phenological stage F1, as described by Ducroquet \& Hickel, 1991) were collected from the cultivars Alcântara, Helena, Mattos and Nonante, and from the accession 2316; the samples were then placed in trays, and immediately transported, under refrigeration $\left(\sim 10^{\circ} \mathrm{C}\right)$, to the laboratory of postharvest physiology and technology, in the Universidade do Estado de Santa Catarina (Udesc), for analysis.

Flower petals were assessed for their colors and surface areas, while the entire flowers were assessed for dry matter (DM), as well as for their contents of soluble solids (SSC), ascorbic acid, anthocyanins, flavonoids, and total phenolic compounds (TPC), and their total antioxidant activity (TAA).

The colors of the petals were determined on the adaxial (colorful) surface for lightness (L), chroma (C), and hue angle $\left(\mathrm{h}^{\circ}\right)$, using a Minolta CR 400 colorimeter (Konica Minolta, Tokyo, Japan). Petal area $\left(\mathrm{cm}^{2}\right)$ was assessed using a LI-COR leaf area integrator (Model LI-3050A, Lincoln, NE, USA). DM (\%) was quantified after leaving the material in an oven at $70^{\circ} \mathrm{C}$ for 72 hours, until constant mass was obtained. SSC ( ${ }^{\circ}$ Brix) was assessed in the extract (undiluted, total volume) collected from the entire flowers (obtained by grinding the tissue with pestle and mortar), using a digital refractometer (Atago, Model PR201 $\alpha$, Tokyo, Japan). The ascorbic acid content $\left[\mathrm{mg} 100 \mathrm{~g}^{-1}\right.$ fresh matter (FW)] was determined by a colorimetric method using 2,4-dinitrophenyl hydrazine, as described by Amarante et al. (2017a).

Anthocyanins and flavonoids were quantified (mg $100 \mathrm{~g}^{-1} \mathrm{FW}$ ) according to the method described by Lees \& Francis (1972).

The procedure to obtain the hydroalcoholic extract for quantification of TPC and TAA was described by Amarante et al. (2017b). TPC [mg gallic acid equivalents (GAE) $100 \mathrm{~g}^{-1} \mathrm{FM}$ ] was quantified using the FolinCiocalteu method, and TAA was determined based on the ability of the extract to scavenge the radicals ABTS [2,2'-azino-bis (3-ethylbenzothiazoline-6-sulphonic acid)] and DPPH (1,1-diphenyl-2-picrylhydrazyl), as described by Amarante et al. (2017b). TAA was expressed as Trolox equivalent antioxidant capacity (TEAC, $\mu$ mol Trolox $\mathrm{g}^{-1} \mathrm{FW}$ ) for ABTS method, and as $\mathrm{EC}_{50}$ (substrate concentration which leads to $50 \%$ reduction of DPPH, determined as $\mathrm{mg} \mathrm{FW} \mathrm{g}^{-1} \mathrm{DPPH}$ ) for DPPH method.

The experiment was carried out in a completely randomized design with five genotypes and four replicates (with 30 flowers and 120 petals by replicate). Since data obtained for all attributes were consistent during the three-year period, only the average values for the three harvests were subjected to the analysis of variance by the SAS software (SAS Institute Inc., Cary, NC, USA), and the means of the treatments were compared by Tukey's test, at 5\% probability.

The petals of feijoa flowers showed an intense color and variations of tonality among the genotypes (Table 1). The adaxial (colorful) surface of the accession 2316 showedanintense dark-bluish violet color, characterized by lower $\mathrm{h}^{\circ}$ and $\mathrm{L}$ values and higher $\mathrm{C}$ values than the other genotypes. 'Helena' showed an intense reddish violet (or pink) color, characterized by higher $\mathrm{h}^{\circ}$ and $\mathrm{C}$ values and intermediate $\mathrm{L}$ values, compared with other genotypes. 'Mattos', 'Nonante', and 'Alcântara' showed an intermediate coloring between dark-bluish violet and reddish violet. The vivid and vibrant color of feijoa petals is very attractive for human consumption, and this attribute is highly desirable for edible flowers used to decorate dishes, salads, and desserts (Lee et al., 2011; Li et al., 2014).

The area of four petals (number of petals within each flower) ranged from $1.59 \mathrm{~cm}^{2}$ in 'Nonante' to 3.91 $\mathrm{cm}^{2}$ in 'Mattos', and DM of entire flowers varied from $10.5 \mathrm{~g}$ in 'Mattos' to $13.3 \mathrm{~g}$ in the accession 2316 (Table 
1). The SSC of entire flowers ranged from $10.10^{\circ}$ Brix in 'Mattos' to $14.17^{\circ}$ Brix in 'Helena' (Table 1), which characterizes the flowers of these genotypes as sweet and attractive for human consumption.

Ascorbic acid content of the entire flowers ranged from $18.6 \mathrm{mg} 100 \mathrm{~g}^{-1} \mathrm{FW}$ ('Helena') to $32.7 \mathrm{mg} 100 \mathrm{~g}^{-1}$ FW ('Alcântara' and 'Nonante') (Table 1). These values are lower than those reported for flowers of Malva sylvestris (111 mg $100 \mathrm{~g}^{-1} \mathrm{FW}$ ) (Barros et al., 2010), and Tropaeolum majus $\left(1,810 \mathrm{mg} 100 \mathrm{~g}^{-1} \mathrm{FW}\right)$ (Bazylko et al., 2014). However, they are higher than the ascorbic acid content reported for fruits, such as passion fruit

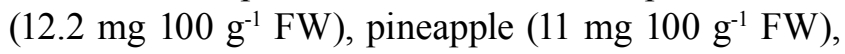
starfruit (2.73 mg $\left.100 \mathrm{~g}^{-1} \mathrm{FW}\right)$, and avocado $(8.53 \mathrm{mg}$ per $100 \mathrm{~g} \mathrm{FW}$ ) (Valente et al., 2011).

Anthocyanin contents ranged from $3.79 \mathrm{mg} 100 \mathrm{~g} \mathrm{~g}^{-1}$ FW in the genotype 'Mattos' to $10.15 \mathrm{mg} 100 \mathrm{~g}^{-1} \mathrm{FW}$ in the accession 2316 (Table 2). Flavonoid contents ranged

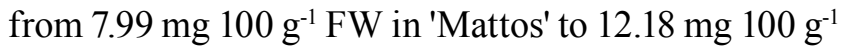

FW in the genotype 'Helena' (Table 2). The TPC ranged from $50.8 \mathrm{mg}$ GAE $100 \mathrm{~g}^{-1} \mathrm{FW}$ ('Mattos') to $70.1 \mathrm{mg}$ GAE $100 \mathrm{~g}^{-1} \mathrm{FW}$ (accession 2316) (Table 2). There was a linear relationship between anthocyanin contents and TPC $\left(\mathrm{y}=2.4127 \mathrm{x}+41.632, \mathrm{R}^{2}=0.8819\right)$ and between flavonoid contents and TPC $(\mathrm{y}=3.3055 \mathrm{x}+26.267$, $\left.\mathrm{R}^{2}=0.7509\right)$. Anthocyanin contents and TPC were highly correlated in Sophora viciifolia flowers (Tai et al., 2011) and in petals of Rosa hybrida cv. Noblered (Lee et al., 2011).

TAA was significantly different between genotypes, as 'Mattos' showed the lowest TAA values, and the accession 2316 the highest ones, regardless of the essay method used (DPPH or ABTS) (Table 2). There was a linear relationship between TPC and TAA, assessed by ABTS and DPPH methods (Figure 1). Therefore, phenolic compounds are the major contributors to the TAA in feijoa flowers, as reported for other flowers (Li et al., 2014).

Table 1. Color attributes (lightness $=\mathrm{L}$; chroma $=\mathrm{C}$; and hue angle $=\mathrm{h}^{\circ}$ ) on the adaxial (colorful) surface of petals, petal area, and dry matter, and contents of soluble solids (SSC) and ascorbic acid of the entire flower of Brazilian feijoa (Acca sellowiana) genotypes ${ }^{(1)}$.

\begin{tabular}{|c|c|c|c|c|c|c|c|}
\hline \multirow[t]{3}{*}{ Genotype } & \multicolumn{4}{|c|}{ Petal } & \multicolumn{3}{|c|}{ Entire flower } \\
\hline & \multicolumn{3}{|c|}{ Color } & \multirow{2}{*}{$\begin{array}{l}\text { Area }^{(2)} \\
\left(\mathrm{cm}^{2}\right)\end{array}$} & \multirow{2}{*}{$\begin{array}{c}\text { Dry matter } \\
(\mathrm{g})\end{array}$} & \multirow{2}{*}{$\begin{array}{c}\mathrm{SSC} \\
\left({ }^{\circ} \text { Brix }\right)\end{array}$} & \multirow{2}{*}{$\begin{array}{c}\text { Ascorbic acid } \\
\left(\mathrm{mg} 100 \mathrm{~g}^{-1} \mathrm{FW}\right)\end{array}$} \\
\hline & $\mathrm{L}$ & $\mathrm{C}$ & $\mathrm{h}^{\mathrm{o}}$ & & & & \\
\hline Alcântara & $44.26 c$ & $27.89 a$ & $353.96 b c$ & $2.87 \mathrm{c}$ & $12.321 \mathrm{ab}$ & $11.03 \mathrm{c}$ & $32.724 a$ \\
\hline Mattos & $52.62 \mathrm{a}$ & $21.45 b$ & $348.48 \mathrm{c}$ & $3.91 \mathrm{a}$ & $10.487 \mathrm{c}$ & $10.10 \mathrm{~d}$ & $22.333 b$ \\
\hline Helena & $41.62 \mathrm{cb}$ & 29.31a & $359.17 \mathrm{a}$ & $3.13 b c$ & $11.823 b$ & $14.17 \mathrm{a}$ & $18.578 b$ \\
\hline Nonante & $48.98 b$ & $17.91 b$ & $352.46 \mathrm{bc}$ & $1.59 \mathrm{~d}$ & $11.414 b c$ & $12.42 b$ & $32.714 a$ \\
\hline Accession 2316 & $39.48 d$ & $28.06 \mathrm{a}$ & $335.13 d$ & $3.49 \mathrm{ab}$ & $13.311 \mathrm{a}$ & $11.15 \mathrm{c}$ & $19.912 b$ \\
\hline Mean & 45.39 & 24.91 & 349.84 & 2.99 & 11.871 & 11.75 & 25.252 \\
\hline $\mathrm{CV}(\%)$ & 18.1 & 36.9 & 48.7 & 7.18 & 4.59 & 1.85 & 12.68 \\
\hline
\end{tabular}

${ }^{(1)}$ Means followed by equal letters within the columns do not differ by Tukey's test, at $5 \%$ probability. ${ }^{(2)}$ Area of four petals (number of petals within each flower). The means refer to averages from 2012, 2013, and 2014.

Table 2. Anthocyanins, flavonoids, total phenolic compounds, and total antioxidant activity (by ABTS and DPPH methods) of entire flowers of Brazilian feijoa (Acca sellowiana) genotypes ${ }^{(1)}$.

\begin{tabular}{|c|c|c|c|c|c|}
\hline \multirow[t]{2}{*}{ Genotype } & \multirow{2}{*}{$\begin{array}{l}\text { Anthocyanins } \\
\left(\mathrm{mg} 100 \mathrm{~g}^{-1} \mathrm{FW}\right)\end{array}$} & \multirow{2}{*}{$\begin{array}{c}\text { Flavonoids } \\
\left(\mathrm{mg} 100 \mathrm{~g}^{-1} \mathrm{FW}\right)\end{array}$} & \multirow{2}{*}{$\begin{array}{c}\text { Total phenolic } \\
\text { compounds } \\
\left(\mathrm{mg} \mathrm{GAE} 100 \mathrm{~g}^{-1} \mathrm{FW}\right)^{(2)}\end{array}$} & \multicolumn{2}{|c|}{ Total antioxidant activity } \\
\hline & & & & $\begin{array}{c}\text { ABTS } \\
\left(\mu \mathrm{mol} \text { Trolox } \mathrm{g}^{-1} \mathrm{FW}\right)\end{array}$ & $\begin{array}{c}\mathrm{DPPH} \\
\left(\mathrm{EC}_{50}{ }^{(3)} ; \mathrm{mg} \mathrm{FW} \mathrm{g}^{-1} \mathrm{DPPH}\right)\end{array}$ \\
\hline Alcântara & $8.77 \mathrm{~b}$ & $11.22 \mathrm{a}$ & $61.223 \mathrm{c}$ & $22.858 \mathrm{~b}$ & $4.717 \mathrm{bc}$ \\
\hline Mattos & $3.79 \mathrm{~d}$ & $7.99 \mathrm{c}$ & $50.817 \mathrm{~d}$ & $14.057 \mathrm{~d}$ & $9.014 \mathrm{a}$ \\
\hline Helena & $10.12 \mathrm{a}$ & $12.18 \mathrm{a}$ & $63.186 \mathrm{~b}$ & $20.512 \mathrm{c}$ & $5.147 \mathrm{bc}$ \\
\hline Nonante & $5.27 \mathrm{c}$ & $8.19 b$ & $54.752 \mathrm{~d}$ & $14.397 \mathrm{~d}$ & $7.093 b$ \\
\hline Accession 2316 & $10.15 \mathrm{a}$ & $11.47 \mathrm{a}$ & $70.098 \mathrm{a}$ & $23.744 \mathrm{a}$ & $4.071 \mathrm{c}$ \\
\hline Mean & 7.70 & 10.30 & 60.015 & 19.114 & 6.008 \\
\hline CV (\%) & 35.9 & 19.1 & 11.5 & 22.2 & 44.0 \\
\hline
\end{tabular}

(1)Means followed by equal letters within the columns do not differ by Tukey's test, at 5\% probability. The means refer to averages from 2012,2013 , and 2014. ${ }^{(2)} \mathrm{GAE}$, gallic acid equivalent. ${ }^{(3)} \mathrm{EC}_{50}$, substrate concentration which leads to $50 \%$ reduction of the DPPH. 
The values of TPC (from 50.8 to $70.10 \mathrm{mg}$ GAE $100 \mathrm{~g}^{-1} \mathrm{FW}$ ) and TAA assessed by the ABTS method (from 14.1 to $23.7 \mu \mathrm{mol}$ Trolox $\mathrm{g}^{-1} \mathrm{FW}$ ) (Table 2) are within those reported for other edible flowers. Li et al. (2014) evaluated 51 edible and wild flowers, and found TPC values from 13.0 to $1,148 \mathrm{mg}$ GAE $100 \mathrm{~g}^{-1} \mathrm{FW}$, and TAA (ABTS method) from 0.23 to $175.39 \mu \mathrm{mol}$ Trolox g-1 FW.

Physicochemical attributes and functional properties of feijoa flowers differed between the evaluated cultivars. Genotypes with high contents of anthocyanins and flavonoids, and high TPC, showed also a high TAA in the entire flower (accession 2316, 'Alcântara' and 'Helena'). Feijoa flowers show high SSC contents, and represent an important source of phenolic compounds with antioxidant activity.
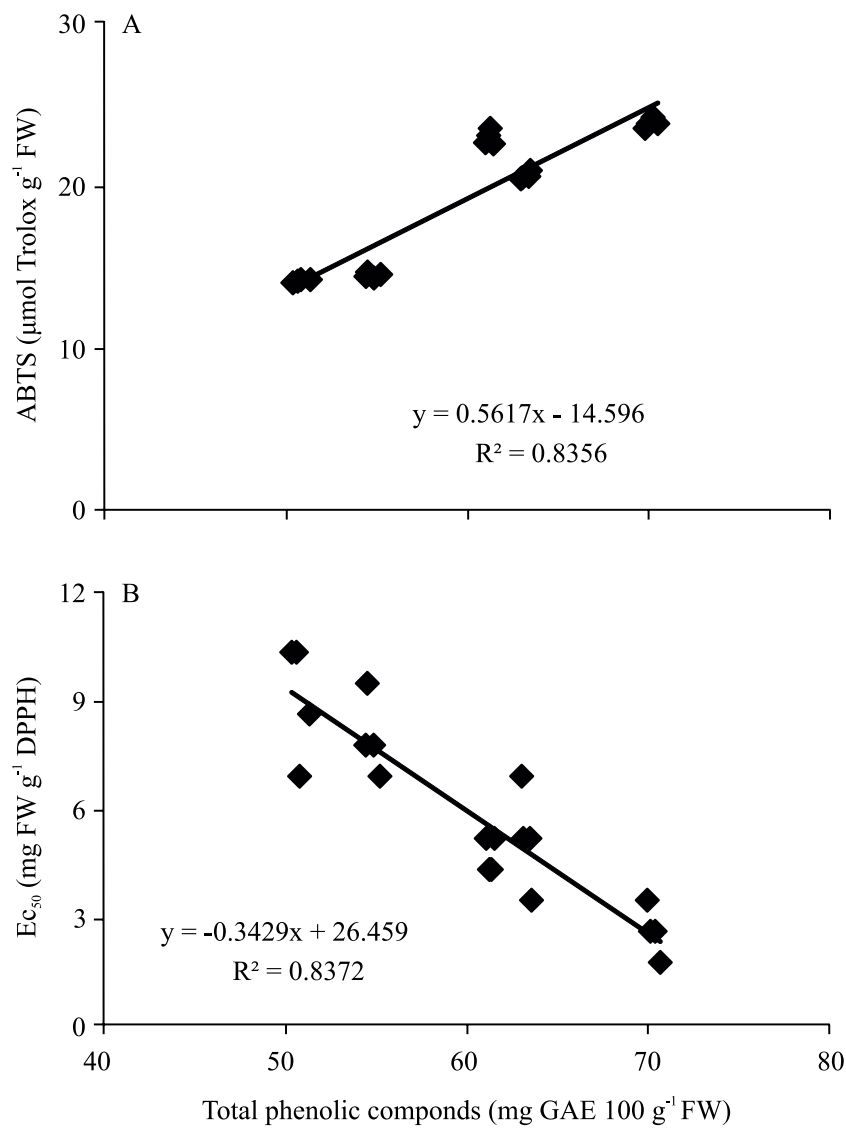

Figure 1. Relationship between total phenolic content and total antioxidant activity assessed by ABTS (A) and DPPH (B) methods of entire flowers of five Brazilian genotypes of feijoa (Acca sellowiana). GAE, gallic acid equivalent. $\mathrm{EC}_{50}$, substrate concentration which leads to $50 \%$ reduction of the DPPH. The means refer to averages from 2012, 2013, and 2014.

\section{Acknowledgments}

To Conselho Nacional de Desenvolvimento Científico e Tecnológico ( $\mathrm{CNPq}$, Process number 301595/2013-5), for financial support; and to Empresa de Pesquisa Agropecuária e Extensão Rural de Santa Catarina (Epagri), Experimental Station of São Joaquim, for supplying feijoa flowers.

\section{References}

AMARANTE, C.V.T. do; SOUZA, A.G. de; BENINCÁ, T.D.T.; STEFFENS, C.A. Fruit quality of Brazilian genotypes of feijoa at harvest and after storage. Pesquisa Agropecuária Brasileira, v.52, p.734-742, 2017a. DOI: https://doi.org/10.1590/S0100$204 X 2017000900005$.

AMARANTE, C.V.T. do; SOUZA, A.G. de; BENINCÁ, T.D.T.; STEFFENS, C.A. Phenolic content and antioxidant activity of fruit of Brazilian genotypes of feijoa. Pesquisa Agropecuária Brasileira, v.52, p.1223-1230, 2017b. DOI: https://doi.org/10.1590/ S0100-204X2017001200011.

BARROS, L.; CARVALHO, A.M.; FERREIRA, I.C.F.R. Leaves, flowers, immature fruits and leafy flowered stems of Malva sylvestris: a comparative study of the nutraceutical potential and composition. Food and Chemical Toxicology, v.48, p.1466-1472, 2010. DOI: https://doi.org/10.1016/j.fct.2010.03.012.

BAZYLKO, A.; PARZONKO, A.; JEZ, W.; OSINSKA, E.; KISS, A.K. Inhibition of ROS production, photoprotection, and total phenolic, flavonoids and ascorbic acid content of fresh herb juice and extracts from the leaves and flowers of Tropaeolum majus. Industrial Crops and Products, v.55, p.19-24, 2014. DOI: https://doi.org/10.1016/j.indcrop.2014.01.056.

DUCROQUET, J.-P.H.J.; HICKEL, E.R. Fenologia da goiabeira serrana (Feijoa sellowiana Berg) no Alto Vale do Rio do Peixe, Santa Catarina. Revista Brasileira de Fruticultura, v.13, p.313320, 1991.

LEE,J.H.; LEE,H.-J.; CHOUNG, M.-G. Anthocyanin compositions and biological activities from the red petals of Korean edible rose (Rosa hybrida cv. Noblered). Food Chemistry, v.129, p.272-278, 2011. DOI: https://doi.org/10.1016/j.foodchem.2011.04.040.

LEES, D.H.; FRANCIS, F.J. Standardization of pigment analyses in cranberries. HortScience, v.7, p.83-84, 1972.

LI, A.-N.; LI, S.; LI, H.-B.; XU, D.-P.; XU, X.-R.; CHEN, F. Total phenolic contents and antioxidant capacities of 51 edible and wild flowers. Journal of Functional Foods, v.6, p.319-330, 2014. DOI: https://doi.org/10.1016/j.jff.2013.10.022.

SOUZA, A.G. de; AMARANTE, C.V.T. do; STEFFENS, C.A.; BENINCÁ, T.DT.; PADILHA, M. Postharvest quality of feijoa flowers treated with different preservative solutions and 1-methylcyclopropene. Revista Brasileira de Fruticultura, v.38, e-759, 2016. DOI: https://doi.org/10.1590/010029452016759. 
TAI, Z.; CAI, L.; DAI, L.; DONG, L.; WANG, M.; YANG, Y.; CAO, Q.; DING, Z. Antioxidant activity and chemical constituents of edible flower of Sophora viciifolia. Food Chemistry, v.126, p.1648-1654, 2011. DOI: https://doi.org/10.1016/j.foodchem.2010.12.048.
VALENTE, A.; ALBUQUERQUE, T.G.; SANCHES-SILVA, A.; COSTA, H.S. Ascorbic acid content in exotic fruits: a contribution to produce quality data for food composition databases. Food Research International, v.44, p.2237-2242, 2011. DOI: https://doi.org/10.1016/j.foodres.2011.02.012. 